\title{
Nilai-Nilai Pendidikan Islam dalam Konsep Manajemen Qalbu Menurut KH. Abdullah Gymnastiar (AA Gym)
}

\author{
Zulfadhly Mukhtar ${ }^{1 *}$, Hakmi Kurniawan ${ }^{2}$, Nurul Zaman ${ }^{3}$, Iskandar Arnel, ${ }^{4}$ Hakmi \\ Wahyudi $^{5}$ Hakmi Hidayat $^{6}$ Syafaruddin ${ }^{7}$ \\ ${ }^{1}$ Sekolah Tinggi Agama Islam Auliarasyidin, Tembilahan Riau, Indonesia \\ ${ }^{2}$ Universitas Islam Negeri Imam Bonjol Padang, Indonesia \\ ${ }^{3}$ Universitas Islam Negeri Sultan Syarif Kasim Riau, Indonesia \\ ${ }^{4}$ Universitas Islam Negeri Sultan Syarif Kasim Riau, Indonesia \\ ${ }^{5}$ Universitas Islam Negeri Sultan Syarif Kasim Riau, Indonesia \\ ${ }^{6}$ Universitas Islam Negeri Maulana Malik Ibrahim Malang, Indonesia \\ ${ }^{7}$ Universitas Islam Negeri Sultan Syarif Kasim Riau, Indonesia \\ E-mail: zulfadhlimukhtar@gmail.com, elhakmi@gmail.com, zaman.nurul82@gmail.com, \\ iskandar.arnel@uin-suska.ac.id midarelhakim1983@uin-suska.ac.id, \\ hakmi.hidayat@uin-malang.ac.id, syafaruddin@uin-suska.ac.id
}

\begin{abstract}
Abstrak
Tujuan dilakukan penelitian ini adalah untuk menganalisis nilai-nilai pendidikan Islam dalam konsep manajemen qalbu menurut KH. Abdullah Gymnastiar.Penelitian ini menggunakan metode penelitianLibrary Research. Adapunanalisisdata menggunakan content analysis. Sedangkansumber data yang penulisgunakan terdiri dari sumber data primer dan datasekunder. Hasil penelitian menunjukkan bahwa nilai-nilai pendidikan Islam dalam konsep manajemen qalbu menurut KH. Abdullah Gymnastiar meliputi: 1) Nilai akidah, seseorang dikatakan beriman apabila keimanan itu telah masuk ke dalam hati seseorang. Dengan kata lain, keimanan merupakan perbuatan qalbu sebagai salah satu bentuk akhlak kepada Allah yang seharusnya berimplikasi pada diri manusia. 2) Nilai ibadah, bahwa bukti keimanan adalah amal shaleh, senang melakukan ibadah dan kebaikan. Amal shaleh akan membawa keberkahan dan rahmat Allah, yang bisa diperoleh dengan hati yang bersih. Keshalehan merupakan kompleksitas sifat dan sikap kepribadian yang bersandarkan pada nilai-nilai keislaman. 3) Nilai akhlak, jika dirinya mengaku beriman kepada Allah maka seharusnya keimanan itu dapat melahirkan akhlak terpuji. Untuk menjadipribadi yang sholeh dan berakhlak mulia maka sebagai manusia kita harus selalu berupaya untuk membersihkan hati dengan tekad yang kuat, mempunyai ilmu dalam memahami diri, mengevaluasi diri dan memberikan kesempatan pada orang lain untuk menilai kita serta selalu mau belajar dan mengambil hikmah dari apa yang terjadi pada diri dan orang lain.
\end{abstract}

Kata Kunci: Pendidikan Islam, Manajemen Qalbu, KH. Abdullah Gymnastiar

\begin{abstract}
The purpose of this research is to analyze the values of Islamic education in the concept of heart management according to KH. Abdullah Gymnastics. This study uses the research method Library Research. The data analysis uses content analysis. While the data sources used consist of primary data sources and secondary data. The results showed that the values of Islamic education in the concept of heart management according to $\mathrm{KH}$. Abdullah Gymnastiar includes: 1) The value of aqidah, someone is
\end{abstract}


believed to believe that "it has entered one's heart. In other words, it is an act of the heart as a form of morality to God which should have implications for humans. 2) The value of worship, proof that I am a righteous deed, happy to do worship and goodness. Good deeds will bring God's blessings and mercy which are obtained with a clean heart. Piety is a personality trait and attitude that is based on Islamic values. 3) Moral values, if he claims to believe in God, he can certainly give birth to commendable morals. To be a pious person and have a noble character, as humans we must always try to clean our hearts with a strong determination, have the knowledge to understand ourselves, develop ourselves and provide opportunities for others to judge us and always want to learn and take lessons from what has been learned. happen to self and others.

Keywords: Islamic Education, Heart Management, KH. Abdullah Gymnastiar

\section{Pendahuluan}

Zaman yang perkembangannya semakin maju seperti sekarang, banyak sekali ditawarkan hal-hal yang dapat menimbulkan kesenangan ataupun hal-hal yang mampu memanjakan diri. Namun di tengah-tengah kesenangan dan kenyamanan yang dirasakan tentunya tidak dapat dipungkiri akan muncul ketidaktentraman batin seperti cemas, was-was, takut, rendah diri, merasa gagal, rasa dengki, iri hati, munafik, riya, marah, dendam dan penyakit hati lainnya.Salah satu perilaku yang banyak dijumpai dalam kehidupan manusia adalah sifat dengki. Seorang pelajar dengki pada teman yang lebih mujur darinya. Seorang artis dengki terhadap teman seprofesi, sebab ia kalah terkenal, dan ibu rumah tangga seperti biasanya merasa dengki pada tetangga yang lebih kaya darinya. ${ }^{1}$ Kedengkian mengakibatkan kerugian besar bagi seseorang. Hariharinya akan diliputi kegelisahan. Tidur tidak nyenyak dan makan pun tidak enak, sebab otaknya dipenuhi pikiran-pikiran negatif. Penyakitnya tak akan hilang kecuali jika ia berusaha mencari obat untuk kesembuhan hatinya. Salah satu caranya adalah dengan manajemen qalbu. ${ }^{2}$

Berdasarkan studi terdahulu yang relevan dengan penulisan ini,Agnitia Citra Resmi, menjelaskan bahwa pesan manajemen qalbu yang terkandung adalah hakikat dari manajemen qalbu itu sendiri yaitu memahami diri, mengevaluasi diri dan mengendalikan diri. ${ }^{3}$ Sedangkan Murtini,memaparkan qalbu memiliki dimensi ruhani yang memiliki fungsi kognisi, emosi, dan spiritual. Selain itu secara umum qalbu memiliki tiga karakteristik antara lain: qalbun salim, qalbun marid, qalbun mayyit, fungsi dan karakteristiknya yang baik akan menjadikan pemilik qalbu itu mempunyai akhlak mulia dan akhlak yang mulia itu merupakan tujuan dari pendidikan Islam. ${ }^{4}$ Darwanto,menjelaskan bahwa manajemen qalbu berpusat pada penataan hati dengan tidak hanya menekankan pada kesalehan individu tapi juga kesalehan sosial, ternyata mampu memberikan sebuah solusi alternatif pada kegelisahan masyarakat

\footnotetext{
hlm. 108.

2Ibid, hlm. 111.

${ }^{3}$ Agnitia Citra Resmi, “Analisis Isi Pesan Manajemen Qalbu dalam Twitter @Aagym (KH. Abdullah Gymnastiar)”, Skripsi Jurusan Komunikasi dan Penyiaran Islam, (Jakarta: UIN Syarif Hidayatullah, 2003).

4Murtini, "Konsep Manajemen Qalbu Menurut Abdullah Gymnastiar Relevansinya dengan Tujuan Pendidikan Islam”, Skripsi Jurusan Pendidikan Agama Islam, (Semarang: IAIN Walisongo, 2010).
}

${ }^{1}$ Abdullah Gymnastiar, Meraih Bening Hati dengan Manajemen Qolbu, (Jakarta: Gema Insani, 2002), 
modern yang banyak mengalami kekeringan spiritual, dan krisis moral dengan cara senantiasa memahami diri yang kemudian menuju proses memperbaiki diri yang akhirnya terbentuklah insan yang memiliki keagungan akhlak dan kesalehan spiritual. ${ }^{5}$

Pendidikan Islam bukan hanya sekedar proses transformasi ilmu dalam kehidupan sosial, akan tetapi nilai-nilai yang terkandung dalam pendidikan Islam juga bertujuan untuk membentuk generasi yang berkarakter dan berakhlak mulia. Tanpa pendidikan Islam manusia tidak akan mencapai semua hal tersebut.Adapun rumusan permasalahan dalam penulisan ini adalah:bagaimana nilai-nilai pendidikan Islam yang terdapat dalam konsep manajemen qalbu menurut KH. Abdullah Gymnastiar. Sebuah konsep manajemen qalbu menurut KH. Abdullah Gymnastiar sebagai solusi atas berbagai permasalahan hidup manusia. Adapun tujuan dilakukannya penulisan ini adalah untuk mengeksplorasi apa saja nilai-nilai pendidikan Islam yang terdapat dalam konsep manajemen qalbu menurut KH. Abdullah Gymnastiar. Sehingga penulisan ini nantinya bermanfaat untuk memberikan sumbangsih kepada khazanah keilmuan bagi para akademsi, para intelektual, dan pembaca yang ingin mengenal lebih dalam konsep yang ditawarkan oleh tokoh ulama KH. Abdullah Gymnastiar yang sering dipanggil AA Gym.

\section{Metode Penelitian}

Adapun jenis penulisan yang penulis gunakan adalahpenulisan kepustakaan (library research). Metode ini digunakan untuk menentukan literatur yang mempunyai hubungan dengan permasalahan yang diteliti. Penulis membaca dan menelaah dari buku-buku bacaan sebagai sumber primer dan didukung dengan sumber-sumber sekunderyang ada kaitannya dengan masalah penulisan ini, yaitu tentang nilai-nilai pendidikan Islam dalam konsep manajemen qalbu menurut KH. Abdullah Gymnastiar. Kemudian penulis menganalisis nilai-nilai pendidikan Islam yang terdapat dalam konsep manajemen qalbu menurut KH. Abdullah Gymnastiar dengan teknik analisis data yaitu content analysis.

\section{Hasil dan Pembahasan}

\section{Pemikiran KH. Abdullah Gymnastiar tentang Manajemen Qalbu}

Menurut KH. Abdullah Gymnastiar (Aa Gym), karakter merupakan masalah inti yang menyebabkan umat Islam banyak tertinggal dalam menjalankan fungsinya sebagai khalifah di muka bumi. Karakter lemah seperti sikap minder, kurang percaya diri, tidak mandiri, dan malas menyebabkan potensi yang ada tidak tergali dan berkembang. Padahal, hal itu bisa menjadi kekuatan nyata guna mengharumkan umat Islam. Demikian pula karakter buruk seperti sikap egois, serakah, dendam, licik dan materialistis, membuat kekuatan dan kemampuan yang ada tidak punya manfaat luas bagi kepentingan ataupun kemajuan umat. Karenanya, sangat dibutuhkan suatu nuansa

${ }^{5}$ Darwanto, "Persepsi Mahasiswa Fakultas Tarbiyah UIN Malang Terhadap Dakwah Manajemen Qalbu (Aa Gym) sebagai Upaya Memperbaiki Diri”, Skripsi jurusan Pendidikan Agama Islam(Malang: Universitas Islam Negeri, 2007) 
dakwah dan sistem pendidikan inovatif yang dapat menyentuh, menggugah, dan mengubah karakter pelbagai lapisan masyarakat menjadi lebih positif. ${ }^{6}$

Selanjutnya, menurut Aa Gym, inti suatu karakter adalah qalbu atau hati nurani. Mengubah karakter mesti diawali dengan upaya mengelola, meluruskan, dan membersihkan hati. Membangun karakter diri sendiri, keluarga, dan tatanan masyarakat pada lingkup apa pun seluruhnya sangat bergantung pada aktivitas hati yang dibuat bersih. Itulah sebabnya, bagi KH. Abdullah Gymnastiar (Aa Gym) setiap keadaan tidap perlu disikapi dengan kekuatan, apalagi kekerasan, namun lebih didasarkan pada sentuhan hati (qalbu), yaitu dengan menggunakan kekuatan manajemen, konsep, dan sumber daya manusia. ${ }^{7}$

Visi KH. Abdullah Gymnastiar (Aa Gym) ini adalah menyatukan dimensi zikir, pikir, dan ikhtiar. Dimensi zikir ini sangat menekankan keikhlasan dan ketawakalan. Sedangkan dimensi pikir amat menegaskan pentingnya rasionalitas dalam setiap pemikiran dan tindakan. Sementara itu, dimensi ikhtiar berfokus pada etos kerja yang tak mengenal lelah dan pasrah. Baginya, ketiga hal tersebut harus ada dalam hati setiap manusia. Interaksi sinergis antara ketiganya akan melahirkan kearifan dan ketangguhan. Itulah substansi dari hal yang disebut konsep manajemen qalbu: mengatasi segala jenis persoalan secara tidak emosional dan egois. ${ }^{8}$

Menurut KH. Abdullah Gymnastiar (Aa Gym), manajemen qalbu berarti mengelola hati supaya potensi positifnya bisa berkembang maksimal mengiringi kemampuan berfikir dan bertindak sehingga sekujur sikapnya menjadi positif, dan potensi negatifnya segera terdeteksi dan dikendalikan sehingga tidak berubah menjadi tindakan yang negatif. ${ }^{9}$ KH. Abdullah Gymnastiar (Aa Gym) juga mengatakan, kata manajemen secara sederhana berarti pengelolaan atau pentadbiran. Artinya sekecil apapun potensi yang ada apabila dikelola dengan tepat, akan dapat terbaca, tergali, tertata, berkembang secara optimal. ${ }^{10}$ Qalbu adalah hati atau lubuk hati yang paling dalam, yang merupakan sarana terpenting yang telah dikaruniakan Allah SWT kepada manusia. Hati adalah tempat bersemayamnya niat, yakni yang menentukan nilai perbuatan seseorang, berharga ataukah sia-sia, mulia atau nista. Niat ini selanjutnya diproses oleh akal pikiran agar bisa direalisasikan dengan efektif dan efesien oleh jasad dalam bentuk amal perbuatan. ${ }^{11}$

\section{Hakikat Manajemen Qalbu}

Inti konsep manajemen qalbu adalah memahami diri dan kemudian kita mau dan mampu mengendalikan diri kita setelah kita memahami benar siapa diri kita sebenarnya. Dan tempat untuk memahami dan mengendalikan diri kita itu ada di hati. Hatilah yang menunjukkan watak dan siapa diri kita sebenarnya. Hati atau "qalbu"-lah

${ }^{6}$ Hernowo \& M. Deden Ridwan, Aa Gym dan Fenomena Daarut Tauhid, (Bandung: Mizan Pustaka, 2003), cet. Ke-XII,hlm. 15-16.

${ }^{7}$ Ibid.

8Ibid., hlm. 16-17.

${ }^{9}$ Abdullah Gymnastiar,Meraih Bening Hati..., hlm.150.

${ }^{10}$ Abdullah Gymnastiar, Jagalah Hati, (Bandung: Khas MQ, 2006), hlm.xvi.

11 Ibid., hlm. xvi-xvii. 
yang membuat kita mampu berprestasi semata demi Allah SWT. Bila hati kita bersih, bening dan jernih, insya Allah SWT, keseluruhan diri kita juga akan menampakkan kebersihan, kebeningan, dan kejernihan. ${ }^{12}$

KH. Abdullah Gymnastiar menjelaskan bahwa: Manajemen Qalbu adalah memahami diri, dan kemudian mau dan mampu mengendalikan diri setelah memahami siapa diri ini sebenarnya. Dan tempat untuk memahami benar siapa diri ini ada di hati, hatilah yang menunjukkan watak dan diri ini sebenarnya. Hati yang membuat diri ini mampu berprestasi semata karena Allah SWT. Apabila hati bersih, bening, dan jernih, tampaklah keseluruhan prilaku diri kita juga akan menampakkan kebersihan, kebeningan, dan kejernihan. Penampilan setiap insan merupakan refleksi dari hatinya sendiri. ${ }^{13}$

Selanjutnya KH. Abdullah Gymnastiar menjelaskan: Manajemen Qalbu ini kemudian melahirkan prinsip bahwa apabila seseorang hatinya bersih, akan menjadi pusat segala aktivitas di bumi. Menyedot seluruh perhatian orang dari segala jenis profesi, baik pedagang, guru, praktisi dakwah, maupun pemimpin. Orang yang hatinya dibuat bersih, secara otomatis akan membuat geraknya memiliki magnet luar biasa. Kata-katanya akan meyakinkan dan menyejukkan hati lawan bicaranya. Sikapnya akan menunjukkan bahwa dia senantiasa sedang diawasi oleh Allah SWT. Totalitas dirinya menampakkan sebuah keadaan bahwa hanya ridha Allah SWT-lah yang diharapkan, Allah SWT menjadi pusat segala orientasi kehidupan. ${ }^{14}$

KH. Abdullah Gymnastiar (Aa Gym) juga menjelaskan bahwasanya: Dalam konsep Manajemen Qalbu, setiap keinginan, perasaan, atau dorongan akan tersaring niatnya sehingga melahirkan suatu kebaikan dan kemuliaan serta penuh dengan manfaat. Tidak hanya bagi kehidupan dunia, tetapi juga untuk kehidupan akhirat kelak. Lebih dari itu, dengan pengelolaan hati yang baik maka seseorang juga dapat merespon segala bentuk aksi atau tindakan dari luar dirinya baik itu positif maupun negatif secara proposional yang terkelola sangat baik akan membuat reaksi yang dikeluarkan menjadi positif dan jauh dari hal-hal mudharat. ${ }^{15}$

Konsep manajemen qalbu memiliki nilai praktis, menurut KH. Abdullah Gymnastiar, segi praktisnya bisa dilihat dari tiga segi: Pertama, manusia memiliki potensi. Potensi itu berupa sarana-sarana yang ada dalam diri seseorang yang berfungsi untuk mengembangkan dan memperbaiki diri. Hanya dengan memiliki niat untuk terus memperbaiki dirilah potensi yang merupakan anugerah dari Allah SWT itu akan menuju kepada-Nya, menuju keadaan yang lebih baik. Dengan kata lain, manusia mempunyai tiga potensi berupa jasad, akal, dan qalbu. Hanya dengan hati atau qalbu yang bersihlah potensi jasad dan akal itu akan terkendalikan dengan baik. Kedua, setiap potensi yang diarahkan kepada kebaikan akan menjadi sangat efektif daya gunanya apabila dimulai dari diri sendiri. Artinya urusilah diri sendiri duhulu sebelum mengurusi orang lain. Perbaikilah diri sendiri dahulu sebelum memperbaiki orang lain. Suruhlah diri sendiri

\footnotetext{
${ }^{12}$ Hernowo dan M. Deden Ridwan, ed., Aa Gym ..., hlm. 226-227.

13Ibid., hlm.25.

14Ibid., hlm. 26

${ }^{15}$ Abdullah Gymnastiar, Jagalah Hati..., hlm. xvii-xviii.
} 
untuk mengerjakan suatu kebaikan sebelum menyuruh orang lain melakukan suatu kebaikan. Apabila ini dapat dilakukan oleh setiap manusia yang sadar akan keadaan dirinya, tentulah akan terjadi sesuatu yang luar biasa. Ketiga, keadaan untuk memperbaiki diri sendiri perlu dibiasakan secara kontinue dan konsisten. Manusia itu pelupa, manusia itu gampang terlena, manusia itu gampang memilih sesuatu yang menyenangkan dirinya. Keadaan menggoda ini harus dilawan setiap hari, bahkan setiap detik. Biasakannlah diri untuk selalu mengingat Allah SWT tentulah Allah SWT akan mengingat kita. ${ }^{16}$

Manusia diciptakan Allah SWT mempunyai nilai istimewa, karena keunggulan yang dimilikinya; sedangkan daging dalam jasadnya bisa mewarnai pikiran, perilaku, juga tuturnya, dialah hati manusia.Menurut KH. Abdullah Gymnastiar (Aa Gym), dengan hati yang semakin bersih dan peka, nanti akan ada semacam 'radar' yang berbunyi di sekitar amal perbuatan kita. Kalau hati makin bersih, nurani atau suara hati yang akan selalu jujur. Yang menutupi suara hati adalah nafsu kita sendiri, jika bisa menahan nafsu maka hati menjadi bersih, nurani pun bisa semakin nyaring dan kuat pengaruhnya dalam diri ini. ${ }^{17}$ Semakin bening hati, semakin peka terhadap ladang amal. Semakin mudah berbuat kebaikan. Ketahuilah rezeki terbesar itu bukanlah sesuatu yang didapatkan, melainkan amal yang dilakukan. ${ }^{18}$

\section{Tahapan Membersihkan Hati}

KH. Abdullah Gymnastiar (Aa Gym) menguraikan ada lima tahapan dalam upaya membersihkan hati, yaitu: Pertama, kita harus menyadari bahwa sesungguhnya tidak ada kesuksesan hakiki yang dapat kita raih di dunia ini. Apabila kita menganggap bahwa kita telah mengalami sebuah kesuksesan, kita sebenarnya sedang ditawari untuk meraih sukses berikutnya yang harus diraih lewat usaha-usaha yang lebih tinggi daripada usaha-usaha sebelumnya. Oleh sebab itu, inilah pentingnya tekad. Upaya membersihkan hati, upaya memahami diri sendiri dan upaya memperbaiki diri kita sendiri, yang kita lakukan setiap hari, memerlukan tekad kuat yang harus terus dinyalakan di dalam diri kita. Tekad yang menyala dan senatiasa berkobar-kobar adalah kunci pertama dalam upaya membersihkan hati.

Kedua, setelah tekad yang harus terus-menerus dinyalakan, kita harus juga memiliki ilmu, mengenai pemahaman atau pengenalan diri kita. Orang baru dapat membersihkan hati dengan jalan terus-menerus memperbaiki keadaan dirinya apabila dia menyadari keadaan dirinya. Sadar tentang keadaan dirinya ini sungguh penting. Inilah ilmu yang perlu kita kuasai setelah kita memiliki tekad untuk memperbaiki diri. Perlu diketahui bahwa ilmu memahami diri ini berbanding lurus dengan tekad. Begitu seseorang dapat meraih keuntungan dalam upaya memahami dirinya, tentulah tekad untuk terus-menerus memperbaiki diri akan bertambah besar pula. Dan semakin besar tekad untuk memperbaiki diri, semakin terus ingin ditambah ilmu mengenai pengenalan diri itu.

\footnotetext{
${ }^{16}$ Hernowo dan M. Deden Ridwan, ed., Aa Gym...., hlm. 227-230.

${ }^{17}$ Abdullah Gymnastiar, Ikhtiar Meraih Ridha Allah, (Bandung: Emqies, 2016), hlm.110-111.

${ }^{18}$ Abdullah Gymnastiar, 30 Hari Menjemput Berkah, (Bandung: Khas MQ, 2005), cet. Ke-2, hlm.17.
} 
Ketiga, berapa banyak waktu dalam hidup kita yang kita sediakan untuk melakukan evaluasi diri. Kita telah tahu ilmunya bahwa sombong itu begini dan begitu kriterianya. Kita juga telah tahu bahwa sombong itu akan mengakibatkan begini dan begitu. Nah, dengan memiliki pengetahuan seperti itu, apakah kemudian kita dapat mengendalikan kesombongan-kesombongan yang ada di dalam diri kita? Apakah kita sudah mengetahui bahwa diri kita itu tidak sombong? Inilah tahapan ketiga yang bisa disebut sebagai menafakuri diri kita sendiri.

Keempat, proses mengevaluasi diri itu perlu terus kita perluas. Apabila tahapan ketiga hanyalah menyangkut diri kita sendiri, yaitu kita dinilai oleh diri kita, pada tahapan keempat ini diri kita dinilai oleh orang lain di luar diri kita. Tentu saja kita tidak usah mencari orang yang jauh yang menilai diri kita. Cukuplah, pada saat awal, yang menilai diri kita adalah anggota keluarga kita. Misalnya istri atau suami kita.

Kelima, atau tahap terakhir, berkaitan dengan proses pembelajaran, yaitu bagaimana diri kita mau belajar kepada diri orang lain. Pada tahapan kelima ini, upaya kita mengendalikan diri dengan cara membersihkan hati, ada sebuah proses yang luar biasa apabila kita mau memahaminya. Bayangkan, hidup menjadi sangat efektif lantaran perilaku orang-orang di sekitar kita itu kita pelajari untuk memperbaiki diri kita. Misalnya ada orang yang kata-katanya gampang menyakiti orang lain. Hidup kita akan menjadi efektif jika kita tidak memberikan komentar atas orang itu dan kita berupaya saja terhindar agar tidak menjadi orang seperti itu. ${ }^{19}$

\section{Analisis Nilai-Nilai Pendidikan Islam dalam Konsep Manajemen Qalbu Menurut KH. Abdullah Gymnastiar}

Hati yang bersih yang dimaksud KH. Abdullah Gymnastiar (Aa Gym) adalah, hati yang terbebas dari syirik, dengki, dendam, kikir, sombong, cinta dunia, dan jabatan. Ia terbebas dari segala penyakit yang dapat menjauhkannya dari Allah SWT, segala syubhat yang dapat menghalangi kebaikannya, nafsu yang bisa menghambat urusannya, keinginan yang mampu merintangi tujuannya, dan penghalang yang merintanginya dari Allah SWT.

Berdasarkan ini penulis berkesimpulan, manajemen qalbu merupakan upaya yang dilakukan seorang individu untukmemahamidiri dengan cara membersihkan, membeningkan, dan menjernihkan hati dan kemudian mau serta mampu mengendalikan diri dari segala hal yang dilarang agama untuk menjadi pribadi yang baik, baik dihadapan Allah SWT maupun kepada sesama manusia semata karena Allah SWT. Melalui konsep manajemen qalbu seseorang bisa diarahkan agar menjadi sangat peka dalam mengelola sekecil apapun potensi yang ada dalam dirinya menjadi sesuatu yang bernilai kemuliaan serta memberi manfaat besar, baik bagi dirinya sendiri maupun orang lain.

Penulis setuju dengan pendapat KH. Abdullah Gymnastiar (Aa Gym) mengatakan, ada beberapa aspek praktis yang harus dipahami, setiap manusia mempunyai ketiga potensi tersebut. Hanya saja, kebanyakan manusia tidak mengoptimalkan potensi yang dimilikinya, sehingga dalam keadaan krisis multi dimensi yang menimpa bangsa ini

${ }^{19}$ Hernowo dan M. Deden Ridwan, ed., Aa Gym...., hlm.234-239. 
ditemui kriminalitas yang merajalela,hal ini tidak lain karena tidak mendayagunakan hati yang dimilikinya dengan baik. Oleh karena itu, diperlukan manajemen qalbu agar potensi positif yang dimiliki hati dapat dioptimalkan. Melalui konsep manajemen qalbu,hati akan memiliki kemampuan memilah mana yang terbaik dan terburuk. Jika seseorang dapat mengoptimalkan kemampuan ini dengan semaksimal mungkin,maka bukan tidak mungkin akan menjadi makhluk yang sempurna, sebab kesempurnaan makhluk itu terletak pada kecerdasan dan kemampuannya dalam mempertimbangkan baik atau buruknya sesuatu.

Berdasarkan pendapat KH. Abdullah Gymnastiar (Aa Gym) tentang lima tahapan dalam upaya membersihkan hati, penulis menyimpulkan manajemen qalbu dapat dilakukan dengan cara:

\section{Pengenalan diri}

Proses pengenalan ataupun memahami diri merupakan salah satu aspek penting yang perlu diperhatikan, karena bagaimanapun sebelum menilai orang lain kita harus terlebih dahulu memahami diri sendiri. Dalam kebaikan pun usahakan diri sendiri dahulu yang mengerjakan kemudian baru mengajak orang lain.

Dalam ayat al-Qur'an disebutkan bahwa sesungguhnya Allah SWT. Tidak akan merubah keadaan suatu kaum sehingga mereka mengubah keadaan yang ada dalam diri mereka sendiri. Terkait dengan konsep pengenalan diri MQ KH. Abdullah Gymnastiar (Aa Gym), ayat tersebut seakan akan mengatakan bahwa untuk memperbaiki dan mengembangkan diri maka yang menjadi fokus pertama kali adalah diri kita sendiri yang tertuang pada suasana dalam hati yaitu hati nurani (persaan). Sebelum mengenal nurani kita maka kita harus mengerti potensi kita. Setelah kita mengetahui potensi kita yang sesungguhnya maka kita akan memaksimalkan kerja kita dengan hanya mengfokuskan potensi yang sudah kita ketahui dalam diri kita sendiri. Namun sering kali bila kita sudah mengetahui diri kita dan sudah fokus. Kita masih mudah terpengaruh oleh keadaan yang ada di sekililing kita. Hal ini perlu kita antisipasi dengan mengubah persepsi yang ada dalam diri kita sendiri jangan sampai kita terpengaruh. Bila yang muncul adalah persepsi negatif maka kita harus berjuang untuk mengubahnya dengan persepsi yang positif.

\section{Membersihkan hati}

Qalbu memiliki potensi untuk berbuat dosa. Ketika seseorang menyembunyikan persaksian dan membenarkan perbuatan itu dalam hatinya maka orang itu termasuk seseorang yang berdosa hatinya. Upaya untuk membersihkan hati adalah dengan memiliki tekad yang kuat untuk terus-menerus memperbaiki diri dan menambah ilmu mengenai pengenalan diri. Menurut penulis hal tersebut dapat dilakukan dengan cara menghindari selalu berprasangka buruk dan upayakan berprasangka baik pada orang lain dalam segala hal. Selalu menjernihkan fikiran terlebih dahulu sebelum menilai segala sesuatu dan yang paling penting adalah selalu beribadah kepada Allah SWT, berdzikir atau mengingat Allah SWT dengan beristighfar memohon ampunan dari Allah SWT. 


\section{Mengevaluasi diri}

Setelah kita memahami diri dan membersihkan hati langkah selanjutnya adalah mengevaluasi diri, bagaimana diri ini bertindak, baik atau buruk maka dilakukan evaluasi diri untuk menuju pribadi seutuhnya yang lebih baik lagi. Upaya mengevaluasi diri ini bertujuan untuk mengetahui kesalahan dari sifat ataupun sikap yang tidak sesuai dengan norma Islam.

\section{Mengendalikan diri}

Mengendalikan diri merupakan upaya yang dilakukan selanjutnya agar tercapai pribadi yang sempurna. Pengendalian diri dapat dilakukan dengan cara membiasakan diri untuk selalu mengingat Allah SWT bahwasanya Dia selalu melihat segala aktivitas yang kita lakukan.

\section{Pengembangan diri}

Pengembangan diri bertujuan untuk meningkatkan potensi diri dan kualitas kepribadian seseorang. Hal ini berkaitan dengan proses pembelajaran, yaitu bagaimana diri kita mau belajar dari diri orang lain.

Melaluikonsep manajemen qalbu KH. Abdullah Gymnastiar (Aa Gym)mengajak seluruh umat muslim untuk memahami dan mengendalikan diri dengan berpusat pada pembersihan hati. Seseorang yang mampu memahami dan kemudian mengembangkan dirinya lewat hati yang bersih,akan senantiasa menunjukkan seluruh gerakan atau kiprahnya untuk mendapatkan ridha Allah SWT.Hanya Allah SWT yang menjadi tujuannya. Setiap hari bahkan setiap detik, perbaikan diri yang dilandasi oleh kebersihan hati senantiasanya dilakukan untuk menuju Allah SWT.HanyaAllah SWT yang mengisi hari-harinya. Hanya Allah SWTyang mengatur gerak-geriknya. HanyaAllah SWTyangkemudianberhakmenentukan akanmenjadiapadirinya.

Jika seseorang tidak bisamengelolahatinya,yang ada hanyaniatingin merugikan oranglain dan membuatoranglain tidak senangdengan apayang telah dilakukannnya. Tindakan kejahatandan kriminalyangseringterdengar dan disaksikan oleh masyarakat, hal itu terjadi karena tidak bisa mengelola hatinya dan menggunakannya untuk berfikir. Di sinilah letak urgensi manajemen qalbu dalam mendidikhati, sebab apabila hati sudah terdidik dan terkelola dengan baik maka akhlak yang baik akantertanam kokohdalam hatidantidakakanmelakukanperilakuyangmerusak.

Sebenarnya manajemen qalbu bukanlah hal baru dalam Islam. Konsep ini hanyalah sebuah format dakwah yang bersumber dari al-Qur'an dan al-Hadits. Hanya inti pembahasannya lebih diperdalam pada masalah pengelolaan hati. Konsep manajemen qalbu ini mengajak orang untuk memahami hati diri sendiri, agar mau dan mampu mengendalikan diri setelah memahami benar siapa dirinya. Manajemen qalbu diidentikkan dengan diri KH. Abdullah Gymnastiar, padahal ide itu sudah tertuang dalam firman Allah SWT dalam al-Qur'an surat asy-Syam/91 ayat 9-10:Sungguh 
beruntunglah orang yang menyucikan jiwa itu dan sesungguhnya merugilah orang yang mengotorinya. ${ }^{20}$

Berdasarkan hadits Rasulullah SAW:Sesungguhnya di dalam tubuhterdapat segumpal daging, apabila ia baik maka semua tubuh menjadi baik, tetapi apabila ia rusak maka semua tubuh menjadi rusak pula. Ingatlah bahwa ia adalah qalbu. (HR. AlBukhari dan Muslim) ${ }^{21}$ Konsep manajemen qalbu yang dibawakan oleh KH. Abdullah Gymnastiar tidak terlepas dari al-Qur'an dan Hadits, dan pada dasarnya manajemen qalbu merupakan upaya memahami diri sendiri, kemudian mau dan mampu memanage hati atau mengendalikan diri dari perbuatan yang sia-sia.

Ketiga pokok nilai-nilai pendidikan Islam yang telah dipaparkan sebelumnya sangatlah penting, karena dengan ditanamkannya ketiga aspek tersebut seseorang akan menjadi manusia seutuhnya (insan kamil) yang memiliki kepribadian utama menurut ajaran Islam. Adapun nilai-nilai pendidikan Islam yang terdapat dalam konsep manajemen qalbu menurut KH. Abdullah Gymnastiar (Aa Gym) akan penulis paparkan berdasarkan ketiga pokok nilai-nilai pendidikan Islam yang telah disebutkan pada bab sebelumnya sebagai berikut:

\section{Nilai Keimanan (i'tiqodiyah)}

KH. Abdullah Gymnastiar (Aa Gym) menjelaskan, bahwasanya diantara ciri orang yang hatinya sehat adalah hidupnya diselimuti mahabbah (kecintaan) dan tawakkal kepada Allah SWT. Tidak heran manakala mencintai sesuatu, maka cintanya sematamata karena Allah SWT. Dengan begitu, ia tidak akan berlebihan mencintai makhluk. Demikian pula bila ia membenci sesuatu maka ia akan membencinya karena Allah SWT semata, sehingga kebenciannya itu tidak akan membuatnya tergelincir ke dalam perbuatan dosa dan aniaya. Semakin bersih hati, hidupnya selalu akan diselimuti rasa syukur. Dikaruniai apa pun, kendati sedikit, ia tidak akan habis-habisnya meyakini bahwa semua yang diterima adalah titipan Allah SWT semata, sehingga amat jauh dari sifat ujub dan takabur. ${ }^{22}$

Seseorang dikatakan beriman apabila keimanan itu telah masuk dalam hati seseorang. Dengan kata lain, keimanan merupakan perbuatan qalbu sebagai salah satu bentuk akhlak kepada Allah SWT yang seharusnya berimplikasi pada diri manusia. Konsekuensi logis dari keimanan adalah mematuhi semua perintah Allah SWT dan menjauhi segala larangan-Nya. Hal inilah yang sebenarnya menjadi orientasi seorang muslim dalam melakukan kebaikan.Namun bukan berarti tanpa iman seseorang tidak mampu melakukan kebaikan, hanya saja apa yang dilakukan itu karena motif-motif tertentu, misalnya bukan karena Allah SWT tapi karena pujian manusia dan lain-lain.

Keimanan juga harus dijadikan alat kontrol yang efektif dalam setiap perbutan yang dilakukan. Hal ini berarti orang yang beriman akan berfikir panjang dalam melakukan perbuatan yang tercela karena dirinya merasa Allah SWT selalu

${ }^{20}$ Ahmad Hatta, Tafsir Qur'an Per Kata, (Jakarta: Maghfirah Pustaka, 2009), hlm.595.

${ }^{21}$ Yon Nofiar, Qolbu Quetient, (Jakarta: PT. Quantum Quality International, 2015), hlm. 59.

${ }^{22}$ Abdullah Gymnastiar, Aku Bisa "Manajemen Qolbu untuk Melejitkan Potensi, (Bandung: Khas MQ, 2005), hlm. 12. 
mengawasinya setiap saat. Dengan demikian, orang yang beriman hatinya akan menjauhi sifat-sifat tercela seperti hasud, sombong, riya', dengki dan lain-lain dengan kata lain hatinya selalu bersih. Hatinya selalu dipenuhi rasa syukur kepadaAllah SWT atas segala nikmat yang telah diberikan dan senantiasa mendekatkan diri kepada-Nya.

\section{Nilai Perbuatan ('amaliyah)}

Pendidikan Islam sangat memperhatikan aspek 'amaliyah karena manfaatnya yang besar bagi kehidupan di dunia berupa kebaikan dan kebahagiaan bagi individu dan masyarakat. Keimanan selalu dikaitkan dengan amal shaleh, karena amal shaleh merupakan manifestasi dari keimanan, bahkan keduanya merupakan rangkaian yang tidak terpisahkan.Amal shaleh akan melahirkan manusia baru yang berhak memperoleh kebaikan, sebab amal shaleh yang dilakukannya akan membuatnya berbeda dari sebelum memperoleh pendidikan akhlak dan amal shaleh.

Bukti keimanan adalah amal shaleh. Amal shaleh akan membawa keberkahan dan rahmat Allah SWT,yang bisa diperoleh dengan hati yang bersih.Keshalehan merupakan kompleksitas sifat dan sikap kepribadian yang bersandarkan pada nilai-nilai keislaman. Iman dan amal shaleh merupakan konsep kunci dan sentral bagi proses perjalanan manusia didunia ini menuju alam akhirat, demi menggapai cita-cita untuk bertemu dengan Allah SWT. Sebagaimana firman Allah SWT dalam al-Quran surat al-Kahfi (18) ayat 110: Barangsiapa mengharap perjumpaan dengan Tuhannya,Maka hendaklah ia mengerjakan amal yang saleh dan janganlah ia mempersekutukan seorang pun dalam beribadat kepada Tuhannya. ${ }^{23}$

Bukti kuatnya iman adalah senang melakukan ibadah dan kebaikan. Melakukan ibadah saja tidak cukup tanpa didasari dengan keikhlasan, karena ruhnya ibadah adalah keikhlasan.Ibadah tanpa didasari dengan keikhlasan hanya akan sia-sia.Kedudukan ikhlas sangat penting dan sangat menentukan setiap amal ibadah.Untuk meraih keikhlasan hanya dapat diperoleh dengan kebersihan hati, sebab semua amal bersumber dari niat dalam hati. Seseorang yang melakukan kebaikan atau amal shaleh segala aktivitasnya akan selalu menghindari hal-hal yang menimbulkan kemudharatan, dan berbuat selalu berlandaskan petunjuk Ilahi, akal sehat dan etika yang baik.

\section{Nilai Etika (khuluqiyah)}

Nilai etika atau akhlak merupakan bagian besar dari pendidikan Islam. Etika merupakan nilai pokok Islam yang bermanfaat bagi manusia serta membuat hidup dan kehidupan yang lebih baik. Etika merupakan alat kontrol secara psikis dan sosial bagi individu dan masyarakat. Tanpa etika, manusia tidak akan berbeda dari kumpulan binatang. Akan tetapi perlu diingat bahwa etika tidak terbatas pada penyusunan hubungan antara manusia dengan manusia lainnya, tetapi melebihi itu juga mengatur hubungan manusia dengan yang terdapat dalam wujud kehidupan ini.

Hubungan hati dengan etika seperti hubungan iman dengan amal shaleh yang merupakan bagian nilai pendidikan Islam. Jika dirinya mengaku beriman kepada Allah SWT maka seharusnya keimanan itu dapat melahirkan akhlak terpuji. Untuk menjadi

${ }^{23}$ Ahmad Hatta, Tafsir Qur'an...., hlm. 304. 
pribadi yang sholeh dan berakhlak mulia maka sebagai manusia harus selalu berupaya untuk membersihkan hati dengan tekad, mempunyai ilmu memahami diri, mengevaluasi diri dan biarkan orang lain menilai kita serta selalu mau belajar dan mengambil hikmah dari prilaku orang lain.

Apabila seseorang telah memilikihatiyangbersihyangtelah terkelola dengan baik, maka akan tercermin dari prilakunya, diantaranya dapat dilihat dari raut muka atau wajahnya. Kalau hati cerah, ceria,senang,tulus, dari wajah juga akan terlihat pancaran ketulusan,dan memancarkan energy yang menyenangkan orang lain dan keikhlasan yang mengharap keridhoan Allah SWTsemata. Etika merupakan manifestasi dari keimanan dan 'amaliyah, artinya keberagamaan menjadi tidak berarti bila tidak dibuktikan dengan etika atau akhlak yang baik.

\section{Simpulan}

Berdasarkan hasil analisis dalam peneltian ini dapat penulis simpulkan bahwa nilai-nilai pendidikan Islam dalam konsep manajemen qalbu menurut $\mathrm{KH}$. Abdullah Gymnastiar (Aa Gym) meliputi:Nilai keimanan (akidah), seseorang dikatakan beriman apabila keimanan itu telahmasuk ke dalam hati seseorang. Dengan kata lain, keimanan merupakan perbuatan qalbu sebagai salah satu bentuk akhlak kepada Allahyangseharusnya berimplikasi pada diri manusia. Nilai perbuatan (ibadah), bahwa bukti keimanan adalah amal shaleh, senang melakukan ibadah dan kebaikan. Amal shaleh akan membawa keberkahan dan rahmat Allah,yang bisa diperoleh dengan hatiyang bersih.Keshalehan merupakan kompleksitas sifat dan sikap kepribadian yang bersandarkan pada nilai-nilai keislaman.Nilai etika (akhlak), jika dirinya mengaku beriman kepada Allah maka seharusnya keimanan itu dapat melahirkan akhlak terpuji. Untuk menjadi pribadi yang sholeh dan berakhlak mulia maka sebagai manusia kita harus selalu berupaya untuk membersihkan hati dengan tekad yang kuat, mempunyai ilmu memahami diri, mengevaluasi diri dan biarkan orang lain menilai kita serta selalu mau belajar dan mengambil hikmah dari prilaku orang lain.

Konsep Manajemen Qalbu menurut KH. Abdullah Gymnastiar sejalan dengan nilai-nilai pendidikan Islam. Hal ini dapat dilihat dari sebuah konsep yang berupaya untuk membentuk seseorang memiliki akhlak yang mulia. Ini berarti mendidik hati dengan konsep Manajemen Qalbumaka akanmemiliki kebiasaan yang terpuji dan mencerminkanakhlak yang mulia. Konsep Manajemen Qalbu menurut Abdullah Gymnastiar adalah membentuk hati yang beriman, menjadikan hati selalu bertaqwa, mengembangkan potensi qalbu.Membersihkan hati dari penyakit-penyakit hati dan membentuk qalbunsalim.Kalau hati bersih maka akhlak pun menjadi baik dan akan produktif melakukan kebaikan yang bermanfaat untuk kemaslahatan dirinya maupun orang lain.

Adapun kelebihan dari konsep manajemen qolbu menurut KH. Abdullah Gymnastiar (Aa Gym) ini adalah dibentuk berdasarkan pada proses perjalanan hidup KH. Abdullah Gymnastiar (Aa Gym) hingga ia menemukan konsep yang lebih praktis dan lebih mudah dipahami namun tetap berlandaskan al-Qur'an dan as-Sunnah. Sehingga konsep manajemen qalbu menurut KH. Abdullah Gymnastiar (Aa Gym) ini 
menarik dan layak untuk diteliti.

\section{Referensi}

Darwanto. (2007). Persepsi Mahasiswa Fakultas Tarbiyah UIN Malang Terhadap Dakwah Manajemen Qalbu (Aa Gym) sebagai Upaya Memperbaiki Diri, Skripsi Jurusan Pendidikan Agama Islam, Malang: Universitas Islam Negeri.

Gymnastiar, A. (2002). Meraih Bening Hati dengan Manajemen Qalbu, Jakarta: Gema Insani Press.

Gymnastiar, A. (2005a). 30 Hari Menjemput Berkah, Bandung: Khas MQ.

Gymnastiar, A. (2005b). Aku Bisa "Manajemen Qolbu untuk Melejitkan Potensi, Bandung: Khas MQ.

Gymnastiar, A. (2006a). Aa Gym Apa Adanya, Bandung: Khas MQ.

Gymnastiar, A. (2006b). Jagalah Hati, Bandung: Khas MQ.

Gymnastiar, A. (2016). Ikhtiar Meraih Ridha Allah, Bandung: Emqies Publishing.

Hamdi, M.H., Yuliharti, Yanti. (2020). Pemikiran Pendidikan Islam Ibnu Khaldun 1332 M, Kutubkhanah: Jurnal Penelitian Sosial Keagamaan, Vol.20 No. 2, h. 121-136.

Hatta, A. (2009). Tafsir Qur'an Perkata, Jakarta: Maghfirah Pustaka.

Hernowo \& Ridwan, M.D. (2004). Aa Gym dan Fenomena Daarut Tauhiid, Bandung:Mizan.

Huda, F., Yuliharti, Yanti. (2020) Pemikiran Pendidikan Islam Pada Masa Nabi \& Khulafaurrasyidin, Kutubkhanah: Jurnal Penelitian Sosial Keagamaan, Vol.20 No. 2, 137-151.

Murtini. (2010). Konsep Manajemen Qalbu Menurut Abdullah Gymnastiar Relevansinya dengan Tujuan Pendidikan Islam, Skripsi Jurusan Pendidikan Agama Islam, Semarang: IAIN Walisongo.

Nofiar, Y. (2015). Qolbu Quetient, Jakarta: PT. Quantum Quality International.

Puspitasari, Y.S., Yuliharti., Yanti. 2020, Pemikiran Pendidikan Islam Pada Masa Umayyah, Kutubkhanah: Jurnal Penelitian Sosial Keagamaan, Vol.20 No. 2, h. 152161.

Resmi, A. R. (2003) Analisis Isi Pesan Manajemen Qalbu dalam Twitter @Aagym (KH. Abdullah Gymnastiar), Skripsi Jurusan Komunikasi dan Penyiaran Islam, Jakarta: UIN Syarif Hidayatullah.

Zul. D.R. (2020). Pemikiran Pendidikan Islam Menurut Buya Hamka, Kutubkhanah: Jurnal Penelitian Sosial Keagamaan, Vol.20 No. 2, h. 102-120. 